\title{
Pronounced Cell Death in the Absence of NMDA Receptors in the Developing Somatosensory Thalamus
}

\author{
Suzanne M. Adams, ${ }^{1 *}$ Juan Carlos de Rivero Vaccari, ${ }^{2 *}$ and Roderick A. Corriveau ${ }^{2}$ \\ ${ }^{1}$ Department of Anatomy and Cell Biology, Wayne State University, Detroit, Michigan 48201, and 2Department of Cell Biology and Anatomy, Louisiana \\ State University Health Science Center, New Orleans, Louisiana 70112
}

Genetic deletion of NMDA glutamate receptors disrupts development of whisker-related neuronal patterns in the somatosensory system. Independent studies have shown that NMDA receptor antagonists increase cell death among developing neurons. Here, we report that a dramatic feature of the developing somatosensory system in newborn NMDA receptor 1 (NMDAR1) knock-out mice is increased cell death in the ventrobasal nucleus (VB) of the thalamus. Sections were subject to terminal deoxynucleotidyl transferase dUTP nick end labeling staining for apoptotic DNA fragmentation, thionine staining for pyknotic nuclei, silver staining for degenerating cells, and immunostaining for caspase-3. All four methods demonstrated that deletion of NMDAR1 causes a large (on the order of threefold to fivefold) increase in cell death in the VB. The NMDA receptor antagonists dizocilpine maleate (MK-801) and phencyclidine also increase cell death in this structure. The onset of increased cell death in the VB in the absence of NMDA receptor function is approximately the time of birth, overlaps with naturally occurring cell death and synaptogenesis, and displays some anatomical specificity. For example, there was no increase in cell death in the hippocampus or neocortex of NMDAR1 knock-out mice at any of the time points examined: embryonic day 15.5(E15.5), E17.5, and postnatal day 0. We also report a significant reduction in the size of the VB that is evident starting at E17.5. The results indicate that NMDA receptors play a major role in cell survival during naturally occurring cell death in the VB and demonstrate that cell death is a consideration in NMDA receptor knock-out studies.

Key words: development; NMDA receptor; somatosensory; thalamus; cell death; apoptosis

\section{Introduction}

NMDA receptors regulate the formation of precise patterns of synaptic connectivity as well as neuronal cell death in the developing brain. The mechanism of NMDA receptor-dependent synaptic development is thought to be analogous to that of adult synaptic modification, i.e., detection and consolidation of simultaneously active synaptic inputs, whereas asynchronous inputs are weakened and eliminated (Goodman and Shatz, 1993; Constantine-Paton and Cline, 1998). In terms of cell survival, NMDA receptor antagonists increase cell death among immature neurons, and NMDA receptor agonists increase neuronal cell death both during development and in the adult (Gould et al., 1994; Ikonomidou et al., 1999; Monti and Contestabile, 2000; Fiske and Brunjes, 2001; Sattler and Tymianski, 2001; Hardingham and Bading, 2003).

Mystacial vibrissas, highly specialized whiskers on the snout of

Received May 26, 2003; revised Sept. 10, 2004; accepted Sept. 11, 2004.

This work was supported by a Louisiana Board of Regents Research Competitiveness Subprogram award to R.A.C. and by National Institutes of Health Grant R01 NS39050 to R. Erzurumlu. We thank Dr. William Crossland, Dr. Jose Rafols, Connor Patterson, and Powell Kinney for critical reading of this manuscript. We are also grateful to Drs. William Guido, Reha Erzurmulu, Naoaki Sugiura, and Susan Catalano for helpful discussions; Drs. Jeffrey Loeb and Joyce Benjamins for sharing equipment; and Gregory Casey for expert technical assistance.

*S.M.A. and J.C.d.R.V. contributed equally to this work.

Correspondence should be addressed to Dr. Roderick A. Corriveau, Department of Cell Biology and Anatomy, Louisiana State University Health Sciences Center, 1901 Perdido Street, New Orleans, LA 70112. E-mail: rcorri@|suhsc.edu.

DOI:10.1523/JNEUROSCI.3290-04.2004

Copyright $\odot 2004$ Society for Neuroscience $\quad$ 0270-6474/04/249441-10\$15.00/0 rodents, are represented as cluster-like patches at three levels in the trigeminal pathway of the somatosensory system: the brainstem trigeminal complex (BSTC) of the medulla (barrelettes), the ventrobasal complex of the thalamus (barreloids), and the primary somatosensory cortex (barrels) (Woolsey and Van der Loos, 1970; Van der Loos, 1976; Ma, 1991). The whisker representations have served as an important model for determining the role of NMDA receptors in the development of synaptic circuits and have been analyzed in a number of mutant mice with altered electrical activity in the developing brain (Erzurumlu and Kind, 2001). NMDA receptors are composed of the obligatory NMDA receptor 1 (NMDAR1) subunit and at least one of four NMDAR2 subunits (2A-2D) (Kutsuwada et al., 1992; Monyer et al., 1992). Genetic deletion of NMDAR1 or NMDAR2B prevents the appearance of whisker representations in the somatosensory system (Forrest et al., 1994; Li et al., 1994; Kutsuwada et al., 1996; Iwasato et al., 1997, 2000; Rudhard et al., 2003). Taken together, transgenic studies suggest that $\mathrm{Ca}^{2+}$ influx through the NMDA receptor is required for the arrangement of presynaptic terminal arbors and postsynaptic elements into whisker-related patterns but may not be necessary for axonal pathfinding, initial target selection, and coarse map formation.

The development of patterned synaptic connections in subcortical regions of the somatosensory system overlaps with naturally occurring cell death (Ashwell and Waite, 1991; Waite et al., 1992, 2000; Ma, 1993). The specific relationship between NMDA receptor-dependent synaptic development and NMDA receptor- 
dependent cell survival is unknown, however, because they have been addressed by independent studies using either transgenic knock-out mice [synaptic development (Erzurumlu and Kind, 2001)] or pharmacological approaches [synaptic development (Ruthazer and Cline, 2004); cell death (Ikonomidou et al., 2001)]. As a result, it has been unclear whether increased cell death is a feature of NMDA receptor knock-out mice that display defective development of whisker representations. Here, we report that transgenic deletion and pharmacological blockade of NMDA receptors both cause large increases in cell death in the ventrobasal nucleus of the thalamus (VB) during the period of naturally occurring cell death and synaptogenesis. The results raise the possibility that there is a relationship among NMDA receptor function, naturally occurring neuronal cell death, and synaptic pattern formation in the developing somatosensory system.

\section{Materials and Methods}

Animals. NMDAR1 knock-out mice (Li et al., 1994) were originally supplied by Drs. Yuqing Li and Susumu Tonegawa (Massachusetts Institute of Technology, Cambridge, MA), and the mouse colony was a gift from Dr. Carla Shatz (Harvard Medical School, Boston, MA). Animals used in this study were generated by mating NMDAR1 heterozygous $(+/-)$ mice from our inbred colony. Mice were mated overnight, and those that exhibited a vaginal plug the following morning were presumed pregnant. The plug date was considered embryonic day 0.5 (E0.5), with a gestation period of $19.5 \mathrm{~d}$. NMDAR1 knock-out pups $(-/-)$ are born alive and are virtually indistinguishable from wild-type littermates at the time of birth in terms of size, color, and overall morphology (Forrest et al., 1994; Li et al., 1994). NMDAR1 $-/-$ animals do not experience difficulty until $\sim 12$ $\mathrm{hr}$ postnatal, when they start to have respiratory problems. As a result, most NMDAR1 knock-out mice die by $24 \mathrm{hr}$ postnatal (Forrest et al., 1994; Li et al., 1994), limiting studies to prenatal and neonatal time points. All neonates used in this study were taken within $6 \mathrm{hr}$ of birth and appeared healthy. We analyzed the VB in a total of 23 neonatal mice: 4 control wild types, 4 NMDAR1 knock-outs, 4 wild types treated with MK-801, 4 NMDAR1 knock-outs treated with MK-801, 3 wild types treated with phencyclidine (PCP), and 4 NMDAR1 knock-outs treated with PCP. For prenatal brains, the dam was anesthetized by metofane, and the fetuses were rapidly removed. We analyzed the VB in a total of 12 E15.5 mice: 8 wild types and 4 NMDAR1 knock-outs. We analyzed the VB in 13 E17.5 mice: 5 wild types and 8 NMDAR1 knock-outs. Brains were processed in parallel, and adjacent or near adjacent sections were subject to terminal deoxynucleotidyl transferase (TdT) dUTP nick end labeling (TUNEL) staining, thionine staining, silver staining, or caspase-3 immunostaining. The boundary of the VB was determined anatomically on Nissl-stained sections (Altman and Bayer, 1988, 1989; Paxinos and Watson, 1998). Genotyping was done as described by Messersmith et al. (1997). In brief, a tail sample was taken from each mouse and then lysed in buffer (100 mm Tris-HCl, pH 8.8, 0.2\% SDS, $200 \mathrm{~mm}$ $\mathrm{NaCl}, 1 \mathrm{~mm} \mathrm{CaCl}_{2}$, and $100 \mu \mathrm{g} / \mathrm{ml}$ proteinase $\mathrm{K}$ ) overnight at $55^{\circ} \mathrm{C}$. The extracted DNA was precipitated with isopropanol and resuspended in $150 \mu \mathrm{l}$ of $\mathrm{H}_{2} \mathrm{O}$ for at least $1 \mathrm{hr}$ at $65^{\circ} \mathrm{C}$. PCR analysis was performed using a set of neo2 primers (5'-GCAAGGTGAGATGACAGGAGATC and 5' CGCTTGGGTGGAGAGGCTATTC; 284 bp product) and a set of primers targeting the deleted region of the mutant NMDAR1 allele (5'TGACCCTGTCCTCTGCCATG and 5'-GCTTCTCCATGTGCCGGTAC; 510 bp product) to determine the genotype.

Drug treatment. Eleven dams received injections of saline or an NMDA receptor antagonist. The antagonist MK-801 $(0.5 \mathrm{mg} / \mathrm{kg})$ or PCP $(8 \mathrm{mg} /$ $\mathrm{kg}$ ) was administered subcutaneously to the dams starting $24 \mathrm{hr}$ before birth at $t=0,8$, and $16 \mathrm{hr}$. The dose and time course of treatment was adapted from published studies (Ikonomidou et al., 1999). Saline (vehicle) was injected as a control for MK-801 or PCP. For quantification purposes, the saline-treated wild-type neonates $(n=2)$ were used together with the wild-type control neonates $(n=4)$ after confirming that
A

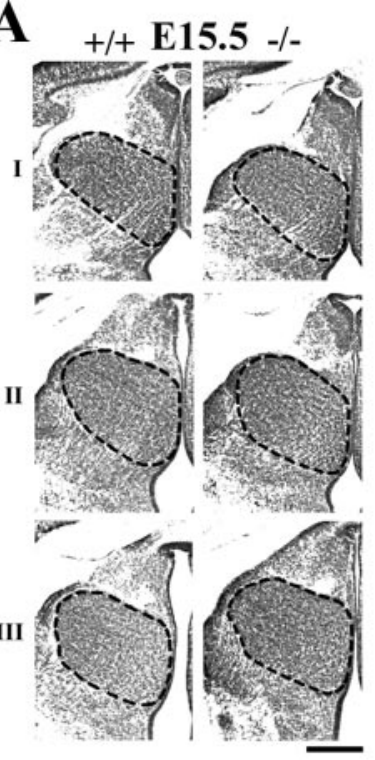

B
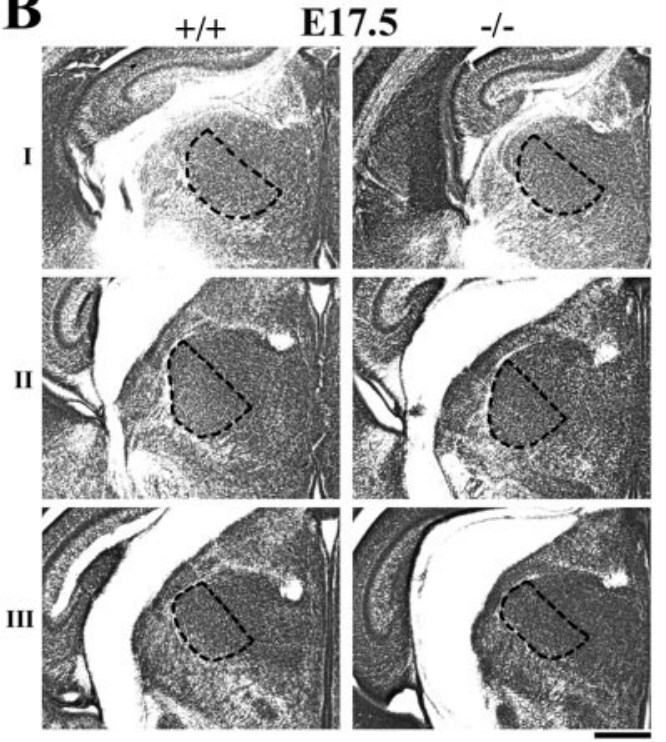

$+/+$

E17.5
C

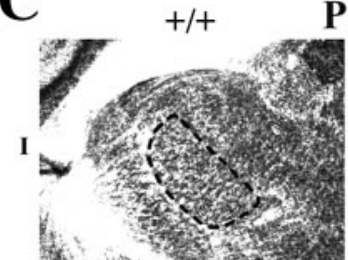

PO

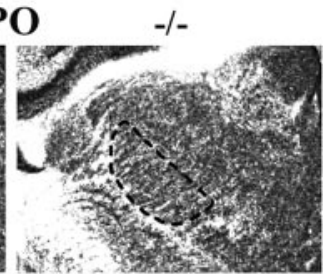

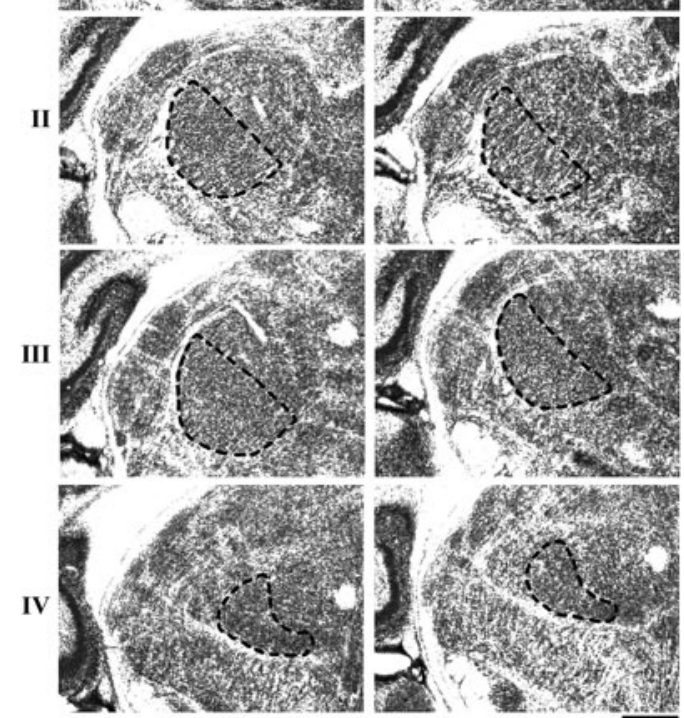

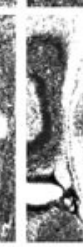

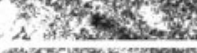

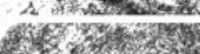

Figure 1. The VB in developing NMDAR1 knock-out $(-/-)$ and wild-type $(+/+)$ mice. Examples of anatomically matched thionine-stained coronal sections used for quantification are shown. In each case, the somatosensory thalamus, or its precursor, is outlined: the IL (precursor to the VB) at E15.5 ( $A$ ), and the VB at E17.5 ( $B)$ and P0 ( $C$ ). Sections were analyzed at three levels (rostral to caudal, I-III) at E15.5 and E17.5 and at four levels (rostral to caudal, I-IV) at P0. Scale bars, $300 \mu \mathrm{m}$. 
A

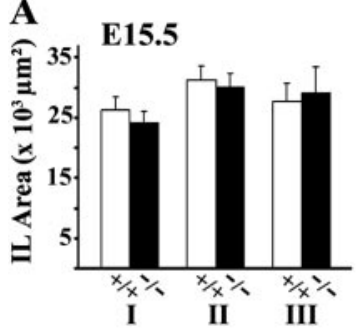

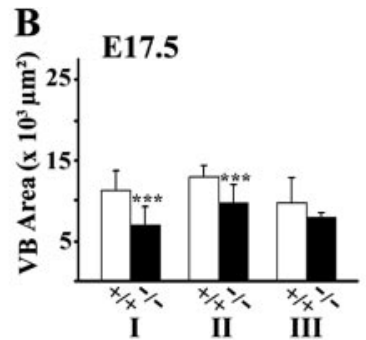

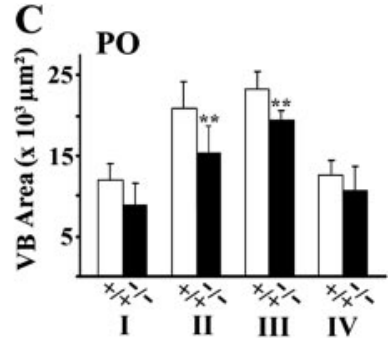

For Nissl staining, sections were first mounted on gelatinized (subbed) slides and then dehydrated in a series of graded alcohols before defatting in xylenes. Sections were then rehydrated and stained with thionine $(0.05 \%$ in acetate buffer, $\mathrm{pH}$ 4.5). Finally, the sections were dehydrated through alcohols, cleared in xylenes, and coverslipped.

Cupric silver staining was performed according to the method described by de Olmos and Ingram (1971). In brief, free-floating sections were rinsed three times in deionized water and transferred to a copper-silver mixture $\left[2.2 \% \mathrm{AgNO}_{3}, 0.0066 \% \mathrm{Cu}\left(\mathrm{NO}_{3}\right)_{2}, 3.5 \%\right.$ pyridine, and $6.7 \%$ ethanol] for $4 \mathrm{~d}$. Sections were then immersed in the following solutions: acetone for $2 \mathrm{~min}$, a diamine-silver solution $(0.24 \%$ $\mathrm{NaOH}, 0.67 \% \mathrm{AgNO}_{3}$, and $\left.9 \% \mathrm{NH}_{4} \mathrm{OH}\right)$ for 7 $\mathrm{min}$, and then reduced in a weak formaldehyde solution $(0.12 \%$ formaldehyde, $0.007 \%$ citric

the results for the two groups were indistinguishable. MK-801 and PCP were purchased from Sigma-Aldrich (St. Louis, MO).

Histology. Neonatal mice were perfused transcardially with wash buffer (in mm: 2 cacodylate, $137 \mathrm{NaCl}, 2 \mathrm{CaCl}_{2}$, and 23 dextrose/sucrose), followed by a cold fixative of $4 \%$ paraformaldehyde in cacodylate buffer, $\mathrm{pH} 7.2$, containing $4 \%$ sucrose. Brains were dissected from the skull and stored in the same fixative at $4^{\circ} \mathrm{C}$. For prenatal animals, the skin and skull were removed to expose the brain, which was then fixed by immersion. After fixation, brains were cryoprotected with 20\% glycerol and 2\% dimethylsulfoxide, embedded in a gelatin matrix, and sectioned coronally at $35 \mu \mathrm{m}$ thick on a freezing microtome (NeuroScience Associates, Knoxville, TN). Neuronal degeneration was assessed by TUNEL staining, Nissl staining (thionine), cupric silver staining, and caspase- 3 immunohistochemistry (NeuroScience Associates). These choices of methodology are similar to and are supported by recent published studies of cell death in the developing rodent brain (Ikonomidou et al., 1999, 2000; Olney et al., 2002a).

TUNEL staining was performed on sections following the instructions in the Apoptag Plus Peroxidase In Situ Apoptosis Detection kit (Chemicon, Temecula, CA). In brief, free-floating sections were placed in 12well plates, rinsed with deionized water, quenched in $3.0 \%$ hydrogen peroxide in PBS for 5 min at room temperature, rinsed with PBS, transferred to equilibration buffer, and then incubated in equilibration buffer in the presence of $\mathrm{TdT}$ for $60 \mathrm{~min}$ at $4^{\circ} \mathrm{C}$. Sections were then placed in stop/wash buffer for $30 \mathrm{~min}$ at $37^{\circ} \mathrm{C}$, incubated with anti-digoxigenin peroxidase-coupled antibody for $30 \mathrm{~min}$ at room temperature, washed in PBS, developed using diaminobenzidine (DAB; $33 \mathrm{mg} / 100 \mathrm{ml}$ in PBS), washed with water, mounted on slides, and coverslipped. acid, and $10 \%$ ethanol) for $1.5 \mathrm{~min}$. After several rinses, the sections were bleached in $0.5 \%$ potassium ferricyanide to eliminate unreduced silver (visually assessed). After several more rinses, sections were mounted on subbed slides, air dried, and then coverslipped.

Caspase-3 immunohistochemistry was performed on free-floating sections. After a wash with PBS, sections were treated with a hydrogen peroxide solution and incubated for $1 \mathrm{hr}$ in a normal blocking serum. Sections were incubated overnight with rabbit anti-caspase- 3 antiserum (polyclonal antibody that recognizes active caspase-3; catalog \#557035; PharMingen, San Diego, CA) diluted 1:600 in blocking solution, followed by a secondary antibody and then by avidin-biotinylated horseradish peroxidase complexes (Vectastain $\mathrm{ABC}$ Elite kit) at room temperature for $2 \mathrm{hr}$. Sections were treated with DAB $(33 \mathrm{mg} / 100 \mathrm{ml}$ in PBS) in the presence of $\mathrm{H}_{2} \mathrm{O}_{2}$ and mounted on gelatinized (subbed) glass slides.

Imaging analysis. Sections were examined by light microscopy, and the images were acquired with either a Kodak DC290 digital camera (Nikon, Tokyo, Japan) or a CoolSnap $c f$ digital camera (Photometrics, Tucson, AZ). The boundary of the VB was identified anatomically (Altman and Bayer, 1988, 1989; Paxinos and Watson, 1998) on thionine-stained sections, and the area of the VB was measured using Adobe Photoshop software. The border of the VB was superimposed on adjacent or near adjacent sections that were processed for TUNEL staining, cupric silver staining, or caspase-3 immunohisochemistry. Quantification of area, pyknotic nuclei, and silver staining was performed, when possible, on both the left and right VB at several rostrocaudal levels. In all quantitative analyses of cell death (pyknotic nuclei, silver staining, and caspase-3), signal over the entire area of the VB was determined on each section

Table 1. Quantification of pyknotic nuclei and area on thionine-stained coronal sections of the somatosensory thalamus from wild-type $(+/+)$ and NMDAR1 knock-out $(-/-)$ mice at E15.5 (IL, the precursor to VB; 3 anatomically matched rostrocaudal levels, I-III), E17.5 (VB; 3 levels, I-III), and PO (VB; 4 levels, I-IV)

\begin{tabular}{|c|c|c|c|c|c|c|}
\hline & \multicolumn{2}{|l|}{ E15.5 } & \multicolumn{2}{|l|}{ E17.5 } & \multicolumn{2}{|l|}{ PO } \\
\hline & $+1+$ & $-1-$ & $+/+$ & $-1-$ & $+/+$ & $-1-$ \\
\hline \multicolumn{7}{|c|}{ Mice:sections ${ }^{a}$} \\
\hline I & 7:14 & 4:7 & $5: 7$ & 8:14 & $4: 6$ & $3: 6$ \\
\hline$\|$ & $8: 16$ & 4:8 & 5:10 & 8:15 & $4: 7$ & $4: 8$ \\
\hline III & $8: 12$ & $4: 8$ & $5: 7$ & $5: 8$ & $4: 8$ & $4: 8$ \\
\hline IV & $\mathrm{N} / \mathrm{A}$ & $\mathrm{N} / \mathrm{A}$ & $\mathrm{N} / \mathrm{A}$ & $\mathrm{N} / \mathrm{A}$ & 3:5 & $3: 4$ \\
\hline \multicolumn{7}{|c|}{ Pyknotic nuclei/ $/ \mathrm{mm}^{2} \pm S D$} \\
\hline I & $72 \pm 19$ & $65 \pm 12$ & $25 \pm 12$ & $40 \pm 45$ & $394 \pm 147$ & $1547 \pm 451$ \\
\hline$\|$ & $70 \pm 19$ & $67 \pm 18$ & $27 \pm 16$ & $39 \pm 33$ & $337 \pm 173$ & $1302 \pm 714$ \\
\hline III & $65 \pm 18$ & $74 \pm 13$ & $24 \pm 20$ & $13 \pm 12$ & $106 \pm 83$ & $974 \pm 225$ \\
\hline IV & $\mathrm{N} / \mathrm{A}$ & $\mathrm{N} / \mathrm{A}$ & $\mathrm{N} / \mathrm{A}$ & $\mathrm{N} / \mathrm{A}$ & $30 \pm 13$ & $120 \pm 79$ \\
\hline \multicolumn{7}{|c|}{$\operatorname{Area}\left(\times 10^{3} \mu \mathrm{m}^{2}\right) \pm S D$} \\
\hline I & $262 \pm 22$ & $243 \pm 17$ & $114 \pm 24$ & $71 \pm 23$ & $120 \pm 21$ & $90 \pm 27$ \\
\hline$\|$ & $312 \pm 24$ & $301 \pm 22$ & $129 \pm 15$ & $98 \pm 22$ & $209 \pm 33$ & $154 \pm 33$ \\
\hline III & $277 \pm 30$ & $292 \pm 42$ & $98 \pm 30$ & $80 \pm 5$ & $232 \pm 23$ & $194 \pm 12$ \\
\hline IV & $N / A$ & $N / A$ & $\mathrm{~N} / \mathrm{A}$ & $\mathrm{N} / \mathrm{A}$ & $126 \pm 18$ & $107 \pm 29$ \\
\hline
\end{tabular}

${ }^{a}$ For each data point, the number of animals and the number of sections analyzed are indicated. 
analyzed. To assess neuronal degeneration by silver staining, images photographed under a total magnification of $40 \times$ were displayed on the computer screen, and the number of pixels representing the silver-stained region within the VB was measured and represented as a percentage of the total number of pixels in the VB (i.e., silver pixels/total pixels). For Nissl-stained sections, pyknotic nuclei were defined by heterochromatin clumping and minimal cytoplasm. Pyknotic nuclei and the number of caspase-3-positive cells were counted under the microscope at a magnification of $400 \times$. Analyses were performed blind to genotype and drug treatment of the animals.

Statistical analysis. For comparisons involving multiple manipulations, i.e., for analyses of pyknotic nuclei and cupric silver staining in NMDAR1 knock-out (control, PCP, and MK801) and wild-type (control, PCP, and MK-801) animals, statistical analyses were performed by two consecutive tests. We first used the KruskalWallis test to determine whether there were significant differences among any of the groups (95\% confidence level), followed by the MannWhitney $U$ test to look for significant differences between specific groups. The Student's $t$ test was used for comparisons involving only two groups (i.e., area measurements and caspase- 3 immunohistochemistry in NMDAR1 wild-type and knock-out animals).

\section{Results}

Neural precursors, including those at all levels of the somatosensory system, express NMDA receptors before or shortly after exiting the cell cycle (LoTurco et al., 1991; Watanabe et al., 1992; Rossi and Slater, 1993; Leamey and Ho, 1998; Akesson, 2000; Maric et al., 2000; Luk et al., 2003). To assess development of the somatosensory thalamus in the absence of NMDA receptors, we first compared area measurements on sections at E15.5, after neurons are present but before most BSTC axons reach the thalamus (Leamey and Ho, 1998; Ding et al., 2003), at E17.5, and at postnatal day 0 (P0), just before the appearance of whisker representations and at the peak of naturally occurring cell death (Yamakodo, 1985; Waite et al., 1992; Ma, 1993). At E15.5, the area of the intermediate lobule (IL), from which the VB is derived (Altman and Bayer, 1988, 1989), was measured at three levels in both wild-type and NMDAR1 knock-out mice (Fig. 1A). At E17.5 and P0, the area of the VB was measured at three and four levels, respectively (Fig. $1 B, C)$. Levels were separated by $175 \mu \mathrm{m}$, and sections of a given age and level were matched anatomically. Quantitative analyses (Fig. 2, Table 1) demonstrate that at E15.5 the area of the IL is indistinguishable between wild-type and NMDAR1 knock-out fetuses at all three levels examined. In E17.5 and P0 animals, however, the average area of the VB is smaller in NMDAR1 knock-out animals than in wild types at all levels analyzed. This difference is statistically significant for two of three levels at E17.5 ( $\sim 30 \%$ smaller $)$ and for two of four levels at P0 ( $\sim 20 \%$ smaller $)$. A smaller area for the VB on sections from NMDAR1 knock-out mice versus wild types is consistent with the finding of a reduced
E17.5
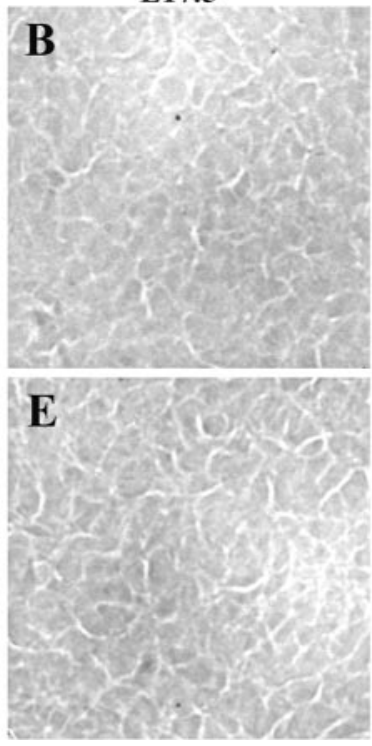
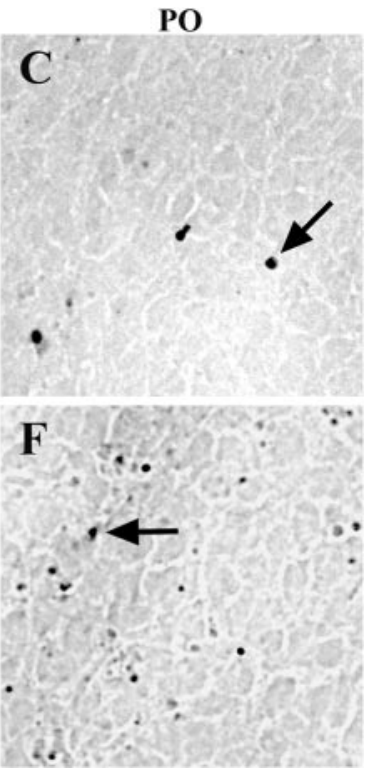

Figure 3. TUNEL staining in the IL (E15.5) and VB (E17.5 and P0) of developing NMDAR1 knock-out (-/-) and wild-type $(+/+)$ mice. Dark staining indicates DNA fragmentation (examples are indicated by arrows). Signal is minimal or absent in both NMDAR1 + $/+$ and NMDAR1 - / - fetuses $(A, B, D, E)$. By P0, there is a significant increase in signal, with more DNA fragmenta-

A

Figure 4. Genetic deletion of NMDAR1 increases the number of pyknotic nuclei in the VB during the peak of naturally occurring cell death. Few pyknotic nuclei are present in the IL at E15.5 $(A)$ and in the VB at E17.5 $(B)$ in both wild-type $(+/+)$ and NMDAR1 k-out $(-I-)$ animals. By $\mathrm{PO}(\mathrm{C})$, however, numerous pyknotic nuclei were observed, and fourfold to ninefold more pyknotic The levels are numbered from rostral to caudal, and sections used for counts of pyknotic nuclei are those used for area measurements (see Fig. 2). The bars represent means \pm SD.

size for the trigeminal nucleus principalis $(\mathrm{PrV})$ in transgenic mice that have a $70 \%$ reduction in NMDA receptor function (Erzurumulu et al., 2002).

Abnormally high levels of cell death might account for the smaller size of the VB in NMDAR1 knock-out animals than in wild-type controls. To test this possibility, we first examined TUNEL-stained sections for apoptotic DNA fragmentation in both wild-type and knock-out mice at E15.5, E17.5, and P0 (Fig. 3). TUNEL staining is minimal or absent in the fetal somatosensory thalamus of both genotypes. Signal increases by P0, and qualitative observations suggest that TUNEL signals in neonates are higher in NMDAR1 knock-outs than in wild-type controls. To corroborate these observations and to compare our results with published quantitative studies (Waite et al., 1992), we counted pyknotic nuclei on thionine-stained sections (Fig. 4, Table 1). In agreement with TUNEL results and published data for normative development (Waite et al., 1992), both wild-type and NMDAR1 knock-out animals display few pyknotic nuclei in the $\mathrm{VB}$ at prenatal times. Moreover, there are no significant differences between NMDAR1 knock-outs and wild types in the num- 

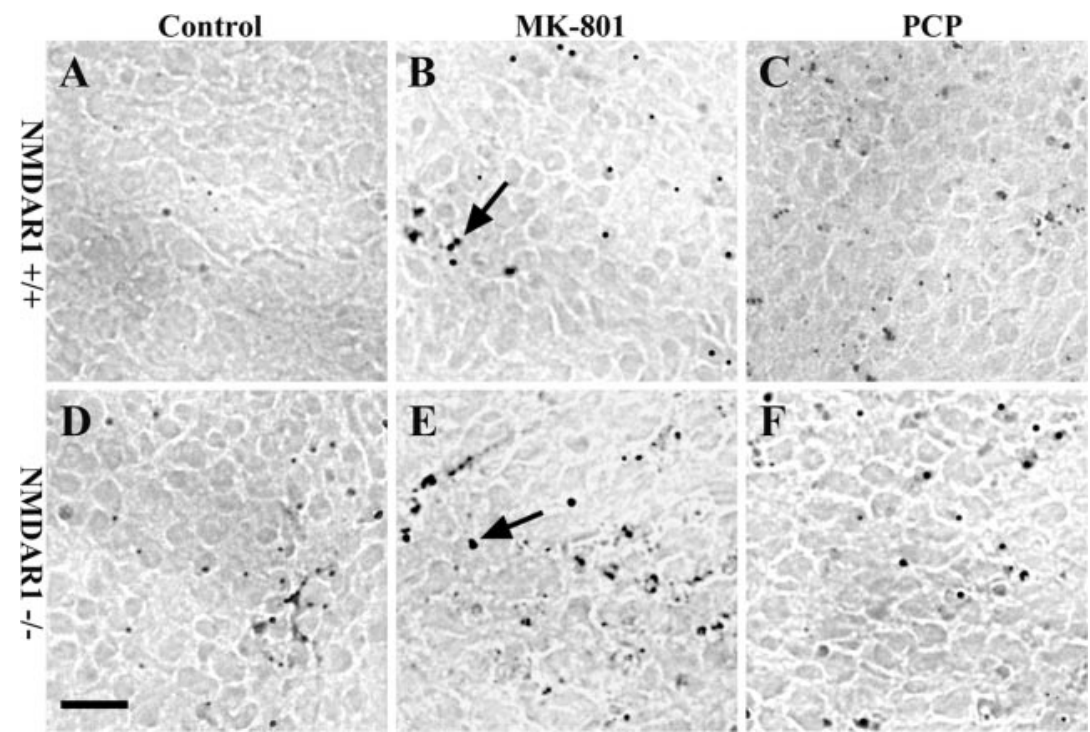

Figure 5. TUNEL staining in the VB of neonatal wild-type $(+/+)$ and NMDAR1 knock-out $(-/-)$ mice treated with vehicle (Control; $A, D)$, MK-801 $(B, E)$, or PCP $(C, F)$. DNA fragmentation is indicated by dark staining (examples are indicated by arrows). Compared with wild-type controls $(A)$, increased TUNEL staining is present in the VB of vehicle-, MK-801-, and PCP-treated knock-out mice (D-F), as well as MK-801- and PCP-treated wild-type mice (B, C). Scale bar, $10 \mu \mathrm{m}$.
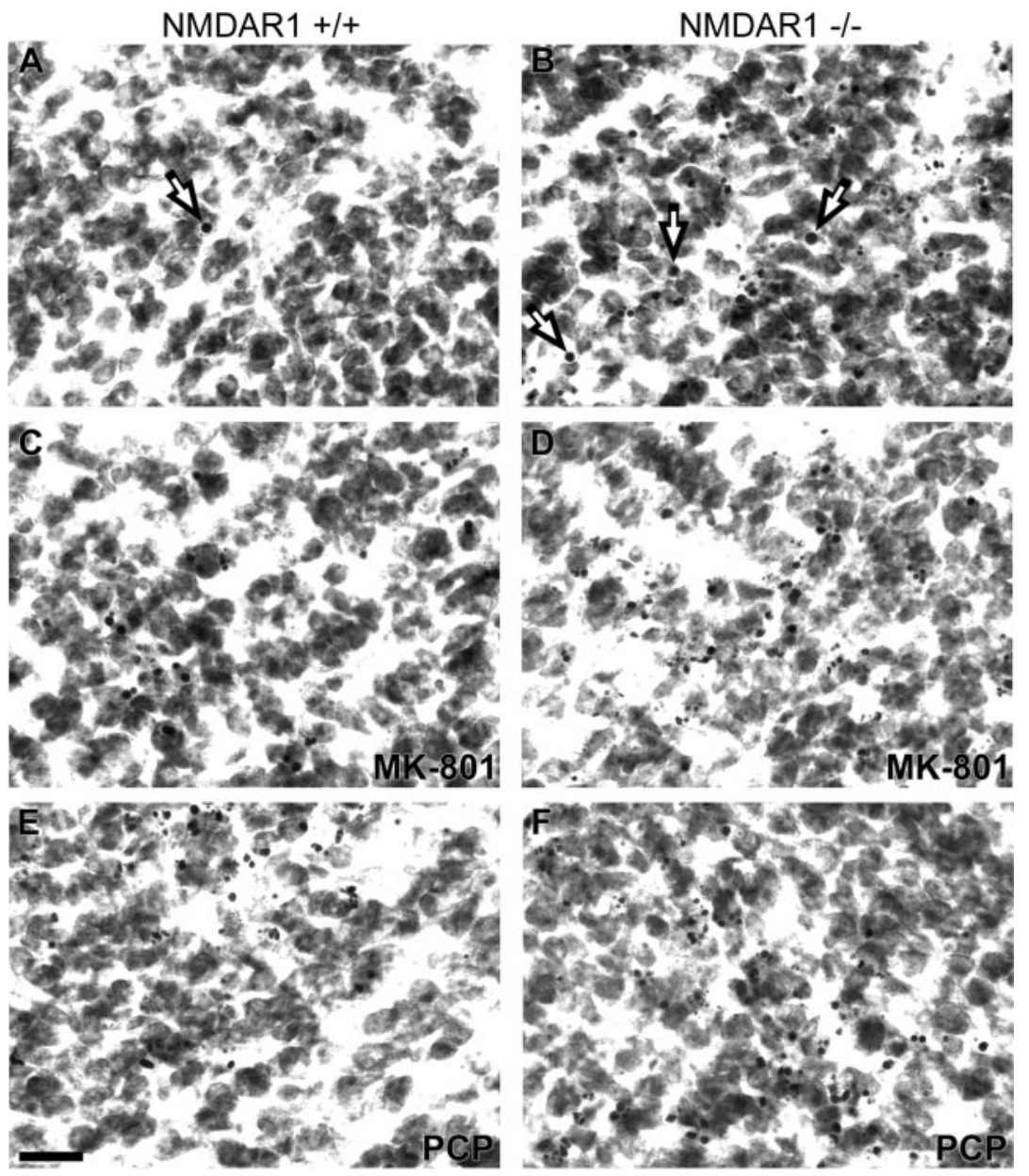

Figure 6. Pyknotic nuclei on thionine-stained sections through the VB from control and NMDA receptor antagonist-treated neonates. $A-F$, Photomicrographs showing examples of pyknotic nuclei in the VB of wild-type control $(A)$, NMDAR1 knock-out control $(B)$, wild type treated with MK-801 (C), NMDAR1 knock-out treated with MK-801 $(D)$, wild type treated with $\mathrm{PCP}(E)$, and NMDAR1 knock-out treated with $P C P(F)$. Compared with wild-type control $(A)$, greater numbers of pyknotic nuclei are present in the VB of NMDAR1 knock-out mice $(B, D, F)$, as well as wild-type mice treated with MK-801 or PCP $(C, E)$. Photomicrographs were taken from level II. The arrows indicate examples of pyknotic nuclei $(A, B)$. Scale bar, $20 \mu \mathrm{m}$. ber of pyknotic nuclei observed in the IL at E15.5 and in the VB at E17.5 (Fig. 4A,B). By $\mathrm{P} 0$, there are numerous pyknotic figures in wild-type VB (Fig. 4C) (Waite et al., 1992). Strikingly, there are up to ninefold more pyknotic nuclei per square millimeter on VB sections from NMDAR1 knock-out neonates than on anatomically matched sections from wild-type controls (Fig. 4C, level III). The increased number of pyknotic nuclei in the $\mathrm{VB}$ of $\mathrm{P} 0$ NMDAR1 knock-out animals versus wildtype controls is statistically significant at all four rostrocaudal levels analyzed. We also observed that there is an anterior (level I) to posterior (level IV) gradient in the abundance of pyknotic nuclei that, to our knowledge, has not been reported previously (Fig. 4C). Although the number of pyknotic nuclei is increased in the absence of NMDAR1, the rostral to caudal gradient remains intact.

To determine whether the high number of pyknotic nuclei observed in the $\mathrm{VB}$ of neonatal NMDAR1 knock-out mice can be attributed directly to the inactivation of NMDA receptors, prenatal mice were treated with the noncompetitive NMDA receptor antagonists MK-801 and PCP on E18.5. Brains were fixed and dissected 24 hr later, i.e., on E19.5, which is equivalent to P0. TUNEL staining was used to examine qualitatively whether there is an increase in DNA fragmentation in the VB of neonates treated with NMDA receptor blockers (Fig. 5). TUNEL signals were higher in animals with decreased NMDA receptor function (wild types and knock-outs treated with MK-801 or PCP and knock-outs treated with vehicle) than in wild-type controls. To confirm these observations, thionine-stained sections were analyzed for pyknotic nuclei (Fig. 6, Table 2) (see Table 2). Quantitative data are represented graphically for levels II and III (Fig. 7), where the area of the VB is largest. Counts of pyknotic nuclei in the VB of wild types treated with MK-801 are higher than in wild-type controls at all four levels analyzed. This increase reaches statistical significance at all levels, except level II (Fig. 7A, Table 2). PCP also caused an increase in pyknotic nuclei counts in wild types compared with wild-type controls at three of four levels analyzed; however, this difference reached statistical significance only at level III (Fig. 7B, Table 2). In no case did treatment of NMDAR1 knock-out animals with MK-801 or PCP cause a significant increase in pyknotic nuclei in the VB versus NMDAR1 knockout alone. This suggests that all three manipulations cause cell death by the same 
Table 2. Quantification of pyknotic nuclei in the VB on thionine-stained coronal sections from control wild-type $(+/+)$ and control NMDAR1 knock-out $(-/-)$ neonates, as well as animals treated with MK-801 or PCP ( 0.5 or $8 \mathrm{mg} / \mathrm{kg}$, s.C., respectively, to dams starting $24 \mathrm{hr}$ before birth at $t=0,8$, and $16 \mathrm{hr}$ )

\begin{tabular}{|c|c|c|c|c|c|c|}
\hline & \multicolumn{2}{|l|}{ PO controls } & \multicolumn{2}{|l|}{ P0 MK-801 } & \multicolumn{2}{|l|}{ POPCP } \\
\hline & $+/+$ & $-1-$ & $+1+$ & $-1-$ & $+1+$ & $-1-$ \\
\hline \multicolumn{7}{|c|}{ Mice:VB } \\
\hline I & $4: 6$ & $3: 6$ & $2: 4$ & 4:6 & $2: 4$ & $4: 7$ \\
\hline$\|$ & $4: 7$ & $4: 8$ & 4:7 & $4: 8$ & 3:5 & $4: 7$ \\
\hline III & $4: 8$ & $4: 8$ & 4:6 & $4: 8$ & $3: 6$ & $4: 8$ \\
\hline IV & $3: 5$ & $3: 4$ & 4:6 & $4: 5$ & $3: 4$ & $4: 8$ \\
\hline \multicolumn{7}{|c|}{ Pyknotic nuclei $/ \mathrm{mm}^{2} \pm S D$} \\
\hline I & $394 \pm 147$ & $1547 \pm 451$ & $1065 \pm 405$ & $799 \pm 412$ & $505 \pm 282$ & $486 \pm 160$ \\
\hline$\|$ & $337 \pm 173$ & $1302 \pm 714$ & $666 \pm 523$ & $1005 \pm 714$ & $738 \pm 554$ & $963 \pm 505$ \\
\hline III & $106 \pm 83$ & $974 \pm 225$ & $397 \pm 232$ & $941 \pm 734$ & $509 \pm 416$ & $1118 \pm 544$ \\
\hline IV & $30 \pm 13$ & $120 \pm 79$ & $95 \pm 46$ & $71 \pm 62$ & $30 \pm 18$ & $51 \pm 15$ \\
\hline
\end{tabular}

Four anatomically matched rostrocaudal levels were analyzed (I-IV). Levels are as in Figure $1 C$.

mechanism, i.e., by decreasing NMDA receptor function (see Discussion for further consideration of pharmacological results).

We used the cupric silver staining method of de Olmos and Ingram (1971) for degenerating cells to further evaluate data obtained in neonates by TUNEL staining and counting pyknotic nuclei. In agreement with preceding experiments, sections of the VB from NMDAR1 knockouts displayed more silver impregnation that those from wild-type controls (Fig. $8 A, B)$, as did the VB on sections from animals treated with NMDA receptor antagonists (Fig. 8C-F). Quantitative results are shown graphically for levels II and III (Fig. 9) and demonstrate statistical signif-

A

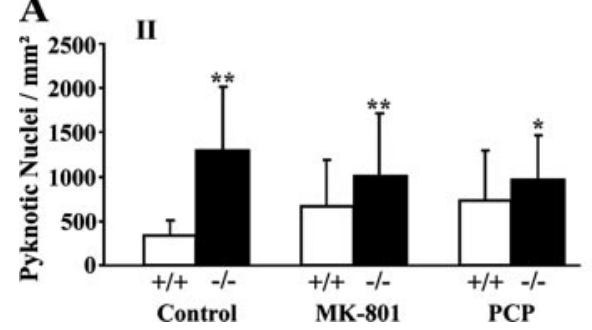

B

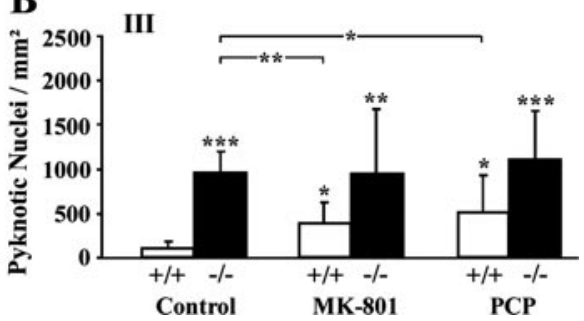

Figure 7. Treatment with NMDA receptor antagonists for $24 \mathrm{hr}$ before birth increases pyknotic nuclei in the VB of wild-type animals but has no effect on NMDAR1 knock-outs. Quantitative results are shown for thionine-stained coronal sections at the two rostrocaudal levels at which the area of the VB is largest (see Fig. 1, Table 1), levels II $(A)$ and III ( $B)$. Each experimental group (NMDAR1 - / - control, NMDAR1 - / - plus MK-801, NMDAR1 - / - plus PCP, NMDAR1 + / + plus MK-801, and NMDAR1 + /+ plus P(P) displays an increase in the number of pyknotic nuclei versus wild-type controls $\left({ }^{*} p<0.05\right.$; ${ }^{* *} p<0.01$; ${ }^{* * *} p<0.001$ ). This difference is not statistically significant at level II for MK801- and PCP-treated NMDAR1 $+/+$ animals. The bars represent means $\pm S D$.

icance in these increased signals at level III, but not at the other levels analyzed (Fig. 9) (data not shown for levels I and IV). There is no increase in cupric silver signals in the VB of NMDAR1 knock-out mice treated with MK-801 or PCP versus NMDAR1 knock-out alone, providing additional evidence that all of these manipulations cause cell death by decreasing NMDA receptor function.

To further verify the results and to begin to characterize the mechanism of cell death in the VB, we used immunohistochemistry to detect the active (cleaved) form of caspase-3, a critical protein for apoptotic cell death (Fig. 10). Consistent with results obtained by TUNEL staining, analysis of pyknotic nuclei, and silver staining, the number of caspase-3-positive cells observed in the VB of NMDAR1 knock-out animals was about threefold higher than in wild-type controls $(p<0.01)$.

The induction of cell death by transgenic or pharmacological manipulation of NMDA receptor function shows some degree of anatomical specificity in these experiments. For example, the hippocampus in neonatal animals displays little, if any, change in silver staining (Fig. 8) or the number of pyknotic nuclei (data not shown) under the various conditions tested. This is also true for the neocortex (data not shown), as has been reported previously for neonatal rats after treatment with MK-801 (Ikonomidou et al., 1999). In addition, silver staining (Fig. 11) and thionine staining for pyknotic nuclei (data not shown) indicate no significant difference between NMDAR1 knock-out and wild-type neonates in the nucleus principalis (PrV) of the BSTC ( $n=3$ wild types, 3 knock-outs; PCP, $n=3$, and MK-801, $n=3$, also had no effect on the PrV at P0). This is significant because the PrV provides the synaptic inputs to the VB that direct the development of barreloids, and the peak of naturally occurring cell death in the PrV is near the time of birth (Killackey and Flemming, 1985; Ashwell and Waite, 1991). Taken together, these results suggest that increased cell death in the VB in the absence of NMDA receptors is not attributable to an overall increase in cell death everywhere in the brain, or even everywhere in the somatosensory system. Moreover, not all types of developing neurons are susceptible to increased cell death in the absence of NMDA receptors.

\section{Discussion}

The present study uses transgenic knock-out and pharmacological blockade of NMDA receptor function to examine the role of NMDA receptors in cell death during neuronal development in vivo. Both transgenic and pharmacological disruption of NMDA receptors cause increased cell death in the developing somatosensory thalamus during the period of naturally occurring cell death and synaptogenesis, indicating that NMDA receptors play a role in the normal development of this structure. The results begin to tie together pharmacological studies demonstrating that NMDA receptor antagonists increase cell death among developing neurons and transgenic knock-out studies demonstrating that NMDA receptors play a critical role in the formation of patterned synaptic connectivity in the somatosensory system.

For cell death analyses, we have chosen to use TUNEL staining for detection of apoptotic DNA fragmentation (Kleine and Tenniswood, 1990; Gavrieli et al., 1992), Nissl staining for pyknotic nuclei (Wyllie et al., 1980), cupric silver staining (method of de Olmos and Ingram, 1971) for degenerating cells (Switzer, 2000), and immunostaining for the apoptotic marker caspase-3 (Porter 

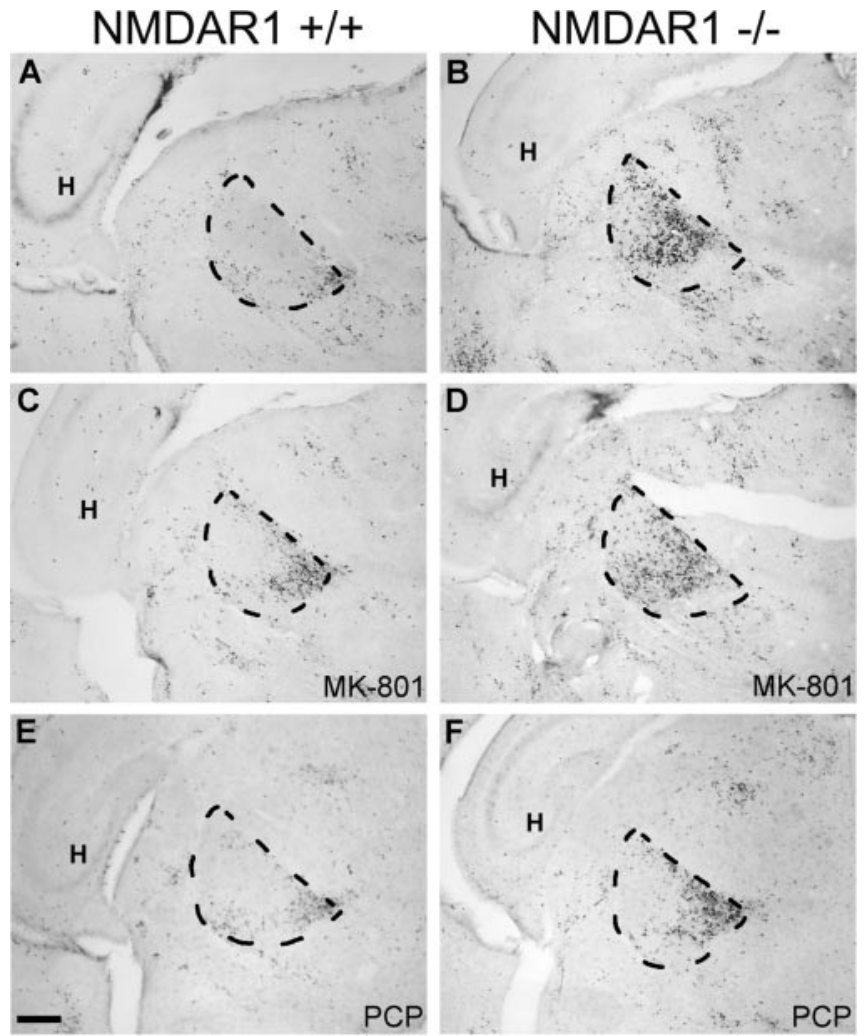

Figure 8. Analysis of degenerating cells in the VB (outlined) by the cupric silver staining method of de Olmos and Ingram (1971). A-F, Low-magnification view of the VB in wild-type control ( $A$ ), NMDAR1 knock-out ( $B$ ), wild type treated with MK-801 (C), NMDAR1 knock-out treated with MK-801 $(D)$, wild type treated with PCP $(E)$, and NMDAR1 knock-out treated with $\mathrm{PCP}(F)$. Degenerating cells are indicated by dark-colored silver impregnation. $\mathrm{H}$, Hippocampus. Scale bar, $200 \mu \mathrm{m}$.

and Janicke, 1999; Abu-Qare and Abou-Donia, 2001). These complementary and independent methods all demonstrated a large increase in cell death in the somatosensory thalamus of neonatal NMDAR1 knock-out mice. Although none of these methods is specific for dying neurons, there are few glial cell bodies present in the VB at P0, and GFAP immunostaining is essentially absent from the thalamus of both wild-type and NMDAR1 knock-out neonates (Parri and Crunelli, 2002; S. Adams and R. Corriveau, unpublished observations). The advantages of using these four techniques together are as follows: (1) TUNEL staining reveals fragmentation of DNA, which is an early characteristic of apoptosis; (2) analysis of pyknotic nuclei by Nissl
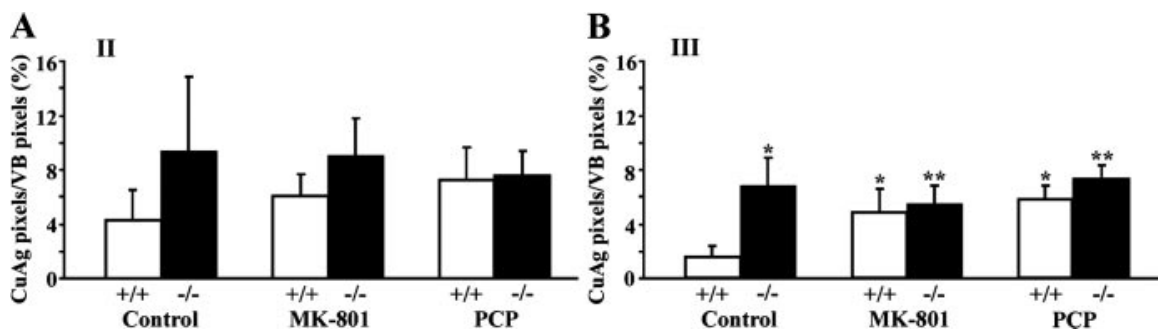

Figure 9. Loss of NMDA receptor function increases silver staining in the VB. The number of pixels of cupric silver signal are expressed as percentages of the total number of pixels in the VB. Quantitative results are shown for coronal sections at the two rostrocaudal levels at which the area of the VB is largest (see Fig. 1, Table 1), levels II $(A)$ and III $(B)$. All five experimental groups (NMDAR1 - / - control, NMDAR1 - / - plus MK-801, NMDAR1 - / - plus PCP, NMDAR1 + / + plus MK-801, and NMDAR1 + /+ plus $P(P)$ display increased silver staining versus wild-type controls $\left({ }^{*} p<0.05{ }^{* *} p<0.01\right)$. These differences are not statistically significant at level II. The bars represent means \pm SD. staining allows, on the same sections, both a quantitative measurement of cell death and a direct evaluation of anatomical parameters (e.g., the area of the VB); (3) silver staining demonstrates argyrophilic extracellular debris that is associated with dying cells and yields strong signals that can be observed at low magnification; and (4) caspase-3 immunostaining complements pyknotic nuclei and silver staining methods by determining the expression of a highly specific molecular marker for dying cells. Furthermore, argyrophilic debris and pyknotic nuclei have longer half-lives in tissue than other markers of cell death, thus providing a longer time window for detection and ultimately more robust signals than obtained by other techniques such as caspase- 3 immunohistochemistry or TUNEL (Robert Switzer, personal communication).

Previous studies used pharmacological agents to demonstrate a link between the survival of immature neurons and NMDA receptor function in various brain regions including the hippocampus (Gould et al., 1994), olfactory bulb (Fiske and Brunjes, 2001), and other parts of the forebrain including the thalamus (Ikonomidou et al., 1999), although the somatosensory thalamus was not addressed specifically. In the present study, MK-801 and PCP increased cell death in the VB of wild-type neonatal mice versus controls, although these increases were not as large as in NMDAR1 knock-out mice and did not always reach statistical significance. This could be because NMDA receptor activity in knock-out animals was eliminated throughout development, whereas wild-type animals were subject to drug treatment for a period of only $24 \mathrm{hr}$. It is also possible that the pharmacological results are complicated by non-NMDA receptor-related activities of MK-801 and PCP. PCP can also block presynaptic $\mathrm{K}^{+}$receptors, resulting in increased synaptic transmission, thus partially counteracting decreased transmission because of its blockade of NMDA receptors (Klein and Kandel, 1980; Bartschat and Blaustein, 1986; Aguayo and Albuquerque, 1987). MK-801 can also block nicotinic receptors (Ramoa et al., 1990; Amador and Dani, 1991; Briggs and McKenna, 1996). Despite these limitations, it is reassuring that $\mathrm{MK}-801$ and $\mathrm{PCP}$ increase cell death in the VB of wild-type animals and do not induce additional cell death in NMDAR1 knock-outs. Taken together, results obtained with NMDAR1 knock-out mice and NMDA receptor antagonists demonstrate an unmistakable role for NMDA receptors in cell survival during VB development in vivo.

Cellular context has a large impact on how the loss of functional NMDA receptors affects cell survival. For example, in separate studies, NMDAR1 knock-out mice were used to generate primary neuronal cell cultures in which the lack of NMDA receptors enhanced the survival of hippocampal neurons and inhibited the survival of Purkinje cells (Yuzaki et al., 1996; Okabe et al., 1998). Deletion of NMDAR1 in weaver mice rescues developing cerebellar granule cells that would otherwise die, presumably because of excitotoxicity (Jensen et al., 1999). Finally, the results reported here and in previous studies demonstrate that a loss of NMDA receptor function increases cell death in only a subset of developing neurons in vivo (Figs. 8, 11) (Ikonomidou et al., 1999), although NMDA receptors are expressed rather ubiquitously in the developing brain (Watanabe et al., 1992). A possible explanation for these differences is that among neurons that are vulnerable to decreased NMDA receptor function, this vulnerability is re- 

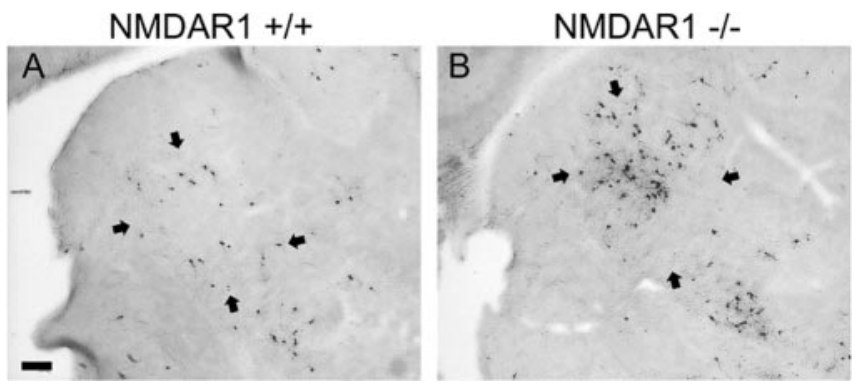

Figure 10. Increased caspase-3 immunostaining in the VB of NMDAR1 knock-out $(B)$ versus wild-type $(A)$ neonates. The arrows indicate the boundary of the VB. Quantification of the number of caspase-3-positive cells within the VB of PO wild-type mice (analysis was at level II; $147 \pm 65$ cell $/ \mathrm{mm}^{2} ; n=7$ sections, 4 animals) and NMDAR1 knock-out mice (51 \pm 33 cell $/ \mathrm{mm}^{2} ; n=9$ sections, 5 animals) demonstrates more caspase-3-positive cells in NMDAR1 knock-outs than in wild-type controls $(p<0.01)$. Scale bar, $100 \mu \mathrm{m}$.
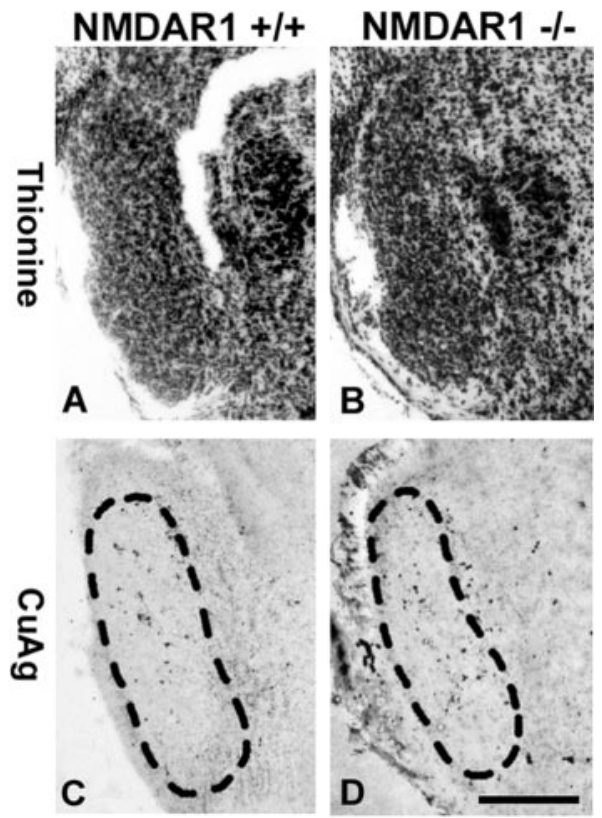

Figure 11. Similar levels of cupric silver staining (CuAg) (method of de Olmos and Ingram, 1971) are present in the PrV of the BSTC in neonatal NMDAR1 wild-type $(+/+)$ and NMDAR1 knock-out $(-/-)$ mice. Thionine-stained $(A, B)$ and silver-stained $(C, D)$ near adjacent coronal sections are shown. The PrV is outlined on silver-stained sections. The group of large cells to the right of the $\operatorname{PrV}$ that is seen in $A$ and $B$ is the motor trigeminal nucleus. Scale bar, $250 \mu \mathrm{m}$.

stricted to the period of naturally occurring cell death. In support of this idea, increased cell death in the VB of NMDAR1 of knockout mice is absent before the onset of naturally occurring cell death. Similarly, we observed no increases in cell death because of decreased NMDA receptor function in the hippocampus or neocortex at the ages examined in this study (E15.5, E18.5, P0), i.e., before the onset of naturally occurring cell death in these structures (Nazarevskaia et al., 1984; Ferrer et al., 1990; Reznikov, 1991; Miller, 1995). Studies by Olney et al. (2002c) using NMDA receptor antagonists documented that increased cell death attributable to decreased NMDA receptor function disappears as the brain matures, providing further indication that neuronal vulnerability to decreased NMDA receptor function is restricted to a specific period of development (Ikonomidou et al., 1999).

In addition to increased cell death, we report a significant reduction in the area of the $\mathrm{VB}$ on sections from NMDAR1 knock-out versus wild-type mice that is evident by E17.5. This is before increased cell death in the VB, suggesting that another NMDA receptor-regulated process is the initial cause of the early decrease in size of the VB. An early decease in the size of the VB may be explained by errors or delays in neuronal migration, such as those induced by pharmacological blockade of NMDA receptors in the developing cerebellum (Komuro and Rakic, 1993) and neocortex (Behar et al., 1999; Hirai et al., 1999). This would be consistent with the timing of neuronal migration in the developing thalamus, which ceases near the time of birth (Parri and Crunelli, 2002). However, an examination of neuronal migration in the neocortex using cell birth-dating techniques found no differences between wild-type and NMDAR1 knock-out mice (Messersmith et al., 1997). Moreover, qualitative studies indicate that NMDAR1 knock-out neural precursors, when transplanted to wild-type developing brains, are capable of migration, survival, and differentiation (Maskos et al., 2001). Quantitative experiments that follow neural precursors of different genotypes through migration and naturally occurring cell death are needed to help clarify the relationship between NMDA receptors, cell migration, and cell death.

NMDA receptors regulate synaptic plasticity during or just after the establishment of appropriate synaptic connections (Goodman and Shatz, 1993; Katz and Shatz, 1996; ConstantinePaton and Cline, 1998). For example, genetic deletion experiments have established an obligatory role for NMDA receptors in the formation of whisker-related patterns of synaptic connectivity at all levels of the developing somatosensory pathway (Erzurumlu and Kind, 2001). The present results indicate that cell death may be a consideration in the interpretation of those studies, although it is not yet known whether there is a causal relationship between NMDA receptor-regulated cell death and NMDA receptor-regulated synaptic development. Nonetheless, the overlap of cell death and synaptogenesis during VB development raises important issues. Based on data presently available, it is possible that defective synaptic development in NMDAR1 knock-out mice causes increased cell death; it is also possible that increased cell death causes defective synaptic development; or, NMDA receptor-regulated synaptogenesis and NMDA receptorregulated cell death could be independent events. It will be important to determine the precise timing of NMDA receptorregulated synaptogenesis and NMDA receptor-regulated cell survival in the VB and other well characterized neural circuits. It may also be informative to investigate whether whisker representations form with increased cell death but normal levels of NMDA receptor function, or with normal levels of cell death but in the absence of NMDA receptor function.

Many drugs that may be abused by pregnant mothers (e.g., ethanol, PCP, and ketamine), as well as some anesthetics used in obstetrics, are NMDA receptor antagonists (Olney et al., $2002 \mathrm{~b}, \mathrm{c})$. The potential consequences for the unborn child are severe. For example, fetal alcohol exposure is the leading cause of mental retardation in Western society (Abel and Sokol, 1987). A better understanding of NMDA receptor-regulated neuronal development is needed for improved prevention and treatment of birth defects caused by decreased levels of NMDA receptor activity in utero. Together with previous studies, our findings facilitate and motivate future experiments that will determine whether there are causal relationships among cellular and molecular events that underlie NMDA receptor-regulated migration, survival, and synaptogenesis in developing neurons. 


\section{References}

Abel EL, Sokol RJ (1987) Incidence of fetal alcohol syndrome and economic impact of FAS-related anomalies. Drug Alcohol Depend 19:51-70.

Abu-Qare AW, Abou-Donia MB (2001) Biomarkers of apoptosis: release of cytochrome c, activation of caspase-3, induction of 8-hydroxy-2'deoxyguanosine, increased 3-nitrotyrosine, and alteration of p53 gene. J Toxicol Environ Health B Crit Rev 4:313-332.

Aguayo LG, Albuquerque EX (1987) Phencyclidine blocks two potassium currents in spinal neurons in cell culture. Brain Res 436:9-17.

Akesson E, Kjaeldgaard A, Samuelsson EB, Seiger A, Sundstrom E (2000) Ionotropic glutamate receptor expression in human spinal cord during first trimester development. Brain Res Dev Brain Res 119:55-63.

Altman J, Bayer SA (1988) Development of the rat thalamus: IV. The intermediate lobule of the thalamic neuroepithelium, and the time and site of origin and settling pattern of neurons of the ventral nuclear complex. J Comp Neurol 284:534-566.

Altman J, Bayer SA (1989) Development of the rat thalamus: I. Mosaic organization of the thalamic neuroepithelium. J Comp Neurol 275:346-377.

Amador M, Dani JA (1991) MK-801 inhibition of nicotinic acetylcholine receptor channels. Synapse 7:207-215.

Ashwell KW, Waite PM (1991) Cell death in the developing trigeminal nuclear complex of the rat. Brain Res Dev Brain Res 63:291-295.

Bartschat DK, Blaustein MP (1986) Phencyclidine in low doses selectively blocks a presynaptic voltage-regulated potassium channel in rat brain. Proc Natl Acad Sci USA 83:189-192.

Behar TN, Scott CA, Greene CL, Wen X, Smith SV, Maric D, Liu QY, Colton CA, Barker JL (1999) Glutamate acting at NMDA receptors stimulates embryonic cortical neuronal migration. J Neurosci 19:4449-4461.

Briggs CA, McKenna DG (1996) Effect of MK-801 at the human alpha 7 nicotinic acetylcholine receptor. Neuropharmacology 35:407-414.

Constantine-Paton M, Cline HT (1998) LTP and activity-dependent synaptogenesis: the more alike they are, the more different they become. Curr Opin Neurobiol 8:139-148.

de Olmos JS, Ingram WR (1971) An improved cupric-silver method for impregnation of axonal and terminal degeneration. Brain Res 33:523-529.

Ding Y-Q, Yin J, Xu H-M, Jacquin MF, Chen Z-F (2003) Formation of whisker-related principal sensory nucleus-based lemniscal pathway requires a paired homeodomain transcription factor, Drg11. J Neurosci 23:7246-7254.

Erzurumlu RS, Kind PC (2001) Neural activity: sculptor of "barrels" in the neocortex. Trends Neurosci 24:589-595.

Erzurumlu RS, Lee L-J, Lo F-S, Iwasato T (2002) Reduced NMDA receptor function alters dendritic morphology of PrV cells but does not affect their membrane properties. Soc Neurosci Abstr 28:130.1.

Ferrer I, Bernet E, Soriano E, del Rio T, Fonseca M (1990) Naturally occurring cell death in the cerebral cortex of the rat and removal of dead cells by transitory phagocytes. Neuroscience 39:451-458.

Fiske BK, Brunjes PC (2001) NMDA receptor regulation of cell death in the rat olfactory bulb. J Neurobiol 47:223-232.

Forrest D, Yuzaki M, Soares HD, Ng L, Luk DC, Sheng M, Steward CL, Morgan JI, Conner JA, Curran T (1994) Targeted disruption of NMDA receptor 1 gene abolishes NMDA response and results in neonatal death. Neuron 13:325-338.

Gavrieli Y, Sherman Y, Ben-Sasson SA (1992) Identification of programmed cell death in situ via specific labeling of nuclear DNA fragmentation. J Cell Biol 119:493-501.

Goodman CS, Shatz CJ (1993) Developmental mechanisms that generate precise patterns of neuronal connectivity. Cell 72 [Suppl]:77-98.

Gould E, Cameron HA, McEwen BS (1994) Blockade of NMDA receptors increases cell death and birth in the developing rat dentate gyrus. J Comp Neurol 340:551-565.

Hardingham GE, Bading H (2003) The Yin and Yang of NMDA receptor signalling. Trends Neurosci 26:81-89.

Hirai K, Yoshioka H, Kihara M, Hasegawa K, Sakamoto T, Sawada T, Fushiki S (1999) Inhibiting neuronal migration by blocking NMDA receptors in the embryonic rat cerebral cortex: a tissue culture study. Brain Res Dev Brain Res 114:63-67.

Ikonomidou C, Bosch F, Miksa M, Bittigau P, Vockler J, Dikranian K, Tenkova TI, Stefovska V, Turski L, Olney JW (1999) Blockade of NMDA receptors and apoptotic neurodegeneration in the developing brain. Science 283:70-74.

Ikonomidou C, Bittigau P, Ishimaru MJ, Wozniak DF, Koch C, Genz K, Price MT, Stefovska V, Horster F, Tenkova T, Dikranian K, Olney JW (2000) Ethanol-induced apoptotic neurodegeneration and fetal alcohol syndrome. Science 287:1056-1060.

Ikonomidou C, Bittigau P, Koch C, Genz K, Hoerster F, Felderhoff-Mueser U, Tenkova T, Dikranian K, Olney JW (2001) Neurotransmitters and apoptosis in the developing brain. Biochem Pharmacol 62:401-405.

Iwasato T, Erzurumlu RS, Huerta PT, Chen DF, Sasaoka T, Ulupinar E, Tonegawa S (1997) NMDA receptor-dependent refinement of somatotopic maps. Neuron 19:1201-1210.

Iwasato T, Datwani A, Wolf AM, Nishiyama H, Taguchi Y, Tonegawa S, Knopfel T, Erzurumlu RS, Itohara S (2000) Cortex-restricted disruption of NMDAR1 impairs neuronal patterns in the barrel cortex. Nature 406:726-731.

Jensen P, Surmeier DJ, Goldowitz D (1999) Rescue of cerebellar granule cells from death in weaver NR1 double mutants. J Neurosci 19:7991-7998.

Katz LC, Shatz CJ (1996) Synaptic activity and the construction of cortical circuits. Science 274:1133-1138.

Killackey HP, Fleming K (1985) The role of the principal sensory nucleus in central trigeminal pattern formation. Brain Res 54:141-145.

Klein M, Kandel ER (1980) Mechanism of calcium current modulation underlying presynaptic facilitation and behavioral sensitization in Aplysia. Proc Natl Acad Sci USA 77:6912-6916.

Kleine L, Tenniswood M (1990) The biochemistry of cell death by apoptosis. Biochem Cell Biol 68:1071-1074.

Komuro H, Rakic P (1993) Modulation of neuronal migration by NMDA receptors. Science 260:95-97.

Kutsuwada T, Kashiwabuchi N, Mori H, Sakimura K, Kushiya E, Araki K, Meguro H, Masaki H, Kumanishi T, Arakawa M, Mishina M (1992) Molecular diversity of the NMDA receptor channel. Nature 358:36-41.

Kutsuwada T, Sakimura K, Manabe T, Takayama C, Katakura N, Kushiya E, Natsume R, Watanabe M, Inoue Y, Yagi T, Aizawa S, Arakawa M, Takahashi T, Nakamura Y, Mori H, Mishina M (1996) Impairment of suckling response, trigeminal neuronal pattern formation, and hippocampal LTD in NMDA receptor epsilon 2 subunit mutant mice. Neuron 16:333-344.

Leamey CA, Ho SM (1998) Afferent arrival and onset of functional activity in the trigeminothalamic pathway of the rat. Brain Res Dev Brain Res 105:195-207.

Li Y, Erzurumlu RS, Chen C, Jhaveri S, Tonegawa S (1994) Whisker-related neuronal patterns fail to develop in the trigeminal brainstem nuclei of NMDAR1 knockout mice. Cell 76:427-437.

LoTurco JJ, Blanton MG, Kriegstein AR (1991) Initial expression and endogenous activation of NMDA channels in early neocrotical development. J Neurosci 11:792-799.

Luk KC, Kennedy TE, Sadikot AF (2003) Glutamate promotes proliferation of striatal neuronal progenitors by an NMDA receptor-mediated mechanism. J Neurosci 23:2239-2250.

Ma PM (1991) The barrelettes-architectonic vibrissal representations in the brainstem trigeminal complex of the mouse. I. Normal structural organization. J Comp Neurol 309:161-199.

Ma PM (1993) Barrelettes-architectonic vibrissal representations in the brainstem trigeminal complex of the mouse. II. Normal post-natal development. J Comp Neurol 327:376-397.

Maric D, Liu Q-Y, Grant GM, Andreadis JD, Hu Q, Chang YH, Barker JL, Pancrazio JJ, Stenger DA, Ma W (2000) Functional ionotropic glutamate receptors emerge during terminal cell division and early neuronal differentiation of rat neuroepithelial cells. J Neurosci Res 61:652-662.

Maskos U, Brustle O, McKay RD (2001) Long-term survival, migration, and differentiation of neural cells without functional NMDA receptors in vivo. Dev Biol 231:103-112.

Messersmith EK, Feller MB, Zhang H, Shatz CJ (1997) Migration of neocortical neurons in the absence of functional NMDA receptors. Mol Cell Neurosci 9:347-357.

Miller MW (1995) Relationship of the time of origin and death of neurons in rat somatosensory cortex: barrel versus septal cortex and projection versus local circuit neurons. J Comp Neurol 355:6-14.

Monti B, Contestabile A (2000) Blockade of the NMDA receptor increases developmental apoptotic elimination of granule neurons and activates caspases in the rat cerebellum. Eur J Neurosci 12:3117-3123. 
Monyer H, Sprengel R, Schoepfer R, Herb A, Higuchi M, Lomeli H, Burnashev N, Sakmann B, Seeburg PH (1992) Heteromeric NMDA receptors: molecular and functional distinction of subtypes. Science 256:1217-1221.

Nazarevskaia GD, Dobrokhotov VN, Reznikov K (1984) Quantitative evaluation of cell proliferation and death in the horn of Ammon and dentate gyrus of the developing hippocampus in the mouse. Biull Eksp Biol Med 98:731-733.

Okabe S, Vicario-Abejon C, Segal M, McKay RD (1998) Survival and synaptogenesis of hippocampal neurons without NMDA receptor function in culture. Eur J Neurosci 10:2192-2198.

Olney JW, Tenkova T, Dikranian K, Muglia LJ, Jermakowicz WJ, D'Sa C, Roth KA (2002a) Ethanol-induced caspase-3 activation in the in vivo developing mouse brain. Neurobiol Dis 9:205-219.

Olney JW, Tenkova T, Dikranian K, Qin YQ, Labruyere J, Ikonomidou C (2002b) Ethanol-induced apoptotic neurodegeneration in the developing C57BL/6 mouse brain. Brain Res Dev Brain Res 133:115-126.

Olney JW, Wozniak DF, Jevtovic-Todorovic V, Farber NB, Bittigau P, Ikonomidou C (2002c) Drug-induced apoptotic neurodegeneration in the developing brain. Brain Pathol 12:488-498.

Parri HR, Crunelli V (2002) Astrocytes, spontaneity, and the developing thalamus. J Physiol (Paris) 96:221-230.

Paxinos G, Watson C (1998) The rat brain in stereotaxic coordinates, Ed 4. San Diego: Academic.

Porter AG, Janicke RU (1999) Emerging roles of caspase-3 in apoptosis. Cell Death Differ 6:99-104.

Ramoa AS, Alkondon M, Aracava Y, Irons J, Lunt GG, Deshpande SS, Wonnacott S, Aronstam RS, Albuquerque EX (1990) The anticonvulsant MK-801 interacts with peripheral and central nicotinic acetylcholine receptor ion channels. J Pharmacol Exp Ther 254:71-82.

Reznikov KY (1991) Cell proliferation and cytogenesis in the mouse hippocampus. Adv Anat Embryol Cell Biol 122:1-74.

Rossi DJ, Slater NT (1993) The developmental onset of NMDA receptorchannel activity during neuronal migration. Neuropharmacology 32:1239-1248.
Rudhard Y, Kneussel M, Nassar MA, Rast GF, Annala AJ, Chen PE, Tigaret CM, Dean I, Roes J, Gibb AJ, Hunt SP, Schoepfer R (2003) Absence of whisker-related pattern formation in mice with NMDA receptors lacking coincidence detection properties and calcium signaling. J Neurosci 23:2323-2332.

Ruthazer ES, Cline HT (2004) Insights into activity-dependent map formation from the retinotectal system: a middle-of-the-brain perspective. J Neurobiol 59:134-146.

Sattler R, Tymianski M (2001) Molecular mechanisms of glutamate receptor-mediated excitotoxic neuronal cell death. Mol Neurobiol 24:107-129.

Switzer 3rd RC (2000) Application of silver degeneration stains for neurotoxicity testing. Toxicol Pathol 28:70-83.

Van der Loos H (1976) Neuronal circuitry and its development. Prog Brain Res 45:259-278.

Waite PM, Li L, Ashwell KW (1992) Developmental and lesion induced cell death in the rat ventrobasal complex. NeuroReport 3:485-488.

Waite PM, Ho SM, Henderson TA (2000) Afferent ingrowth and onset of activity in the rat trigeminal nucleus. Eur J Neurosci 12:2781-2792.

Watanabe M, Inoue Y, Sakimura K, Mishina M (1992) Developmental changes in distribution of NMDA receptor channel subunit mRNAs. NeuroReport 3:1138-1140.

Woolsey TA, Van der Loos H (1970) The structural organization of layer IV in the somatosensory region (SI) of mouse cerebral cortex. The description of a cortical field composed of discrete cytoarchitectonic units. Brain Res 17:205-242.

Wyllie AH, Kerr JF, Currie AR (1980) Cell death: the significance of apoptosis. Int Rev Cytol 68:251-306.

Yamakado M (1985) Postnatal development of barreloid neuropils in the ventrobasal complex of mouse thalamus: a histochemical study for cytochrome oxidase. No To Shinkei 37:497-506.

Yuzaki M, Forrest D, Verselis LM, Sun SC, Curran T, Connor JA (1996) Functional NMDA receptors are transiently active and support the survival of Purkinje cells in culture. J Neurosci 16:4651-4661. 